\title{
Respon pertumbuhan dan produksi padi beras merah (Oryza nivara) terhadap cekaman kekeringan pada fase pertumbuhan berbeda dan pemupukan nanosilika
}

\section{(Response of growth and production of red rice (Oryza nivara) to drought stress in different growth phases and nanosilika fertilization)}

\author{
R. Sugiarto, B. A. Kristanto, D. R. Lukiwati \\ Agroecotechnology, Departement of Agriculture, Faculty of Animal and Agricultural Sciences, \\ Diponegoro University \\ Tembalang Campus, Semarang 50275 - Indonesia \\ Corresponding E-mail: ritasugiarto1995@gmail.com
}

\begin{abstract}
The purpose of this research was to analyze the response of growth and production of red rice (Oryza nivara) under drought and nanosilica fertilization condition. This research was conducted in Greenhouse and Laboratory of and Plant Physiology and Breeding of at Faculty of Animal and Agricultural Sciences, Diponegoro University, Semarang from April to July 2017. The research was arranged using completely randomized factorial design. The first factor was drought stress (control, drought 20-35 DAP (Days After Planting), 40-55 DAP and 55-70 DAP). The second factor was the use of nanosilika fertilizers (without nanosilika, with nanosilica). The data were analyzed by anova and followed by Duncan's Multiple Range Test (DMRT). The results showed that the drought stress during tiller production stage decreased the total number of tillers, productive tillers and grain weight per clump, but not in weight of one thousand seeds. Drought stress during flowering stage and seed filling only decreases the weight of one thousand seeds. Application of nanosilica increases the number of productive tillers and the weight of grain per hill. There was no interaction between drought stress treatment and nanosilika fertilization.
\end{abstract}

Keywords: red rice, production, drought, nanosilica.

\begin{abstract}
ABSTRAK
Penelitian ini bertujuan untuk mengetahui repon pertumbuhan dan produksi padi beras merah (oryza nivara) dalam kondisi tercekam kekeringan dan pemupukan nanosilika. Penelitian dilakukan di Greenhouse dan Laboratorium Fisiologi dan Pemuliaan Tanaman, Fakultas Peternakan dan Pertanian, Universitas Diponegoro, Semarang pada bulan April - Juli 2017. Penelitian disusun menggunakan rancangan acak lengkap faktorial dengan faktor pertama cekaman kekeringan (kontrol, kekeringan umur 20-35 HST (Hari Setelah Tanam), 40-55 HST dan 55-70 HST). Faktor kedua penggunaan pupuk nanosilika (tanpa nanosilika, dengan nanosilika). Data dianalisis ragam dan dilanjutkan dengan Duncan's Multiple Range Test (DMRT). Hasil penelitian menunjukkan cekaman kekeringan fase pembentukan anakan menurunkan jumlah anakan total, anakan produktif dan bobot gabah per rumpun, tetapi tidak pada bobot seribu biji. Cekaman kekeringan fase pembentukan bunga dan pengisian biji hanya menurunkan bobot seribu biji. Pemberian nanosilika meningkatkan jumlah anakan produktif dan bobot gabah per rumpun. Tidak ada Interaksi antara perlakuan cekaman kekeringan dan pemupukan nanosilika.

Kata kunci: padi merah, produksi, kekeringan, nanosilika.
\end{abstract}




\section{PENDAHULUAN}

Padi (Oryza sativa) merupakan jenis tanaman yang diunggulkan pemerintah dalam upaya peningkatan produksi dan swasembada pangan. Produksi gabah kering 65.980.670 ton tidak mencukupi kebutuhan pangan penduduk Indonesia yang mencapai 252.17 juta jiwa dengan tingkat konsumsi beras mencapai $132.98 \mathrm{~kg} / \mathrm{kapita} / \mathrm{tahun}$ (Kementerian Pertanian, 2015). Peningkatan produksi beras menjadi prioritas guna mengatasi kekurangan suplai.

Padi memiliki jenis warna yang beragam diantaranya adalah padi beras putih, merah, hitam, dan coklat (Widyawati et al., 2013). Padi beras merah kurang mendapat perhatian dibanding padi beras putih, Beras merah mengandung nilai gizi yang tidak ada pada beras putih. Keunggulan beras merah adalah mengandung antioksidan berupa senyawa fenolik yang tergolong dalam kelompok flavonoid (Indriyani et al., 2013). Kandungan flanoid diyakini dapat menyembuhkan penyakit kanker, jantung dan mampu menangkal radikal bebas. Kandungan gizi tinggi pada beras merah harusnya menjadi potensi pengembangan lebih luas guna mencukupi kebutuhan pangan dan mendukung program kesehatan masyarakat.

Padi sawah beras merah merupakan hasil persilangan antara padi gogo dengan padi sawah, sehingga padi tersebut dapat ditanam dan beradaptasi di lahan sawah (Balai Penelitian Tanah, 2011). Namun perubahan pola iklim menjadi ancaman yang sangat serius dimasa yang akan datang yaitu kemungkinan terjadinya kekeringan. Kemungkinan resiko gagal panen karena cekaman kekeringan dapat mengancam produksi beras dan ketahanan pangan nasional. Pulau Jawa menyumbang sekitar $44 \%$ produksi beras nasional dan sekitar $20 \%$ diantaranya termasuk ke dalam sawah tadah hujan, oleh karena itu resiko kegagalan panen akibat kekeringan cukup tinggi.

Padi memiliki tiga fase pertumbuhan, yaitu fase vegetatif, fase reproduktif dan fase pematangan (Makarim dan Suhartatik, 2009). Fase-fase pertumbuhan dan perkembangan tersebut merupakan fase kritis jika tanaman mengalami cekaman kekeringan. Cekaman kekeringan pada salah satu atau semua fase pertumbuhan menurunkan hasil bahkan mengalami kegagalan panen. Cekaman kekeringan akan mempengaruhi semua aspek pertumbuhan tanaman, dengan kata lain cekaman kekeringan akan mempengaruhi proses fisiologi dan biokimia tanaman serta menyebabkan terjadinya modifikasi anatomi dan morfologi tanaman.

Silika merupakan salah satu unsur kimia kedua terbanyak di kerak bumi yaitu 27,6\% dan diserap oleh hampir seluruh tanaman dalam bentuk asam monosalisikat (monosilic acid) atau $\mathrm{Si}(\mathrm{OH})_{4}$ (Makarim et al., 2007). Silika banyak terkandung pada tanaman graminae, terutama padi, jagung, dan tebu. Pasokan Si yang cukup pada serealia mampu meningkatkan ketahanan sel, fotosisntesis, dan mengurangi tendensi tanaman untuk layu pada kondisi kekeringan yang disebabkan oleh penurunan permeabilitas atas uap air dari dinding sel epidermal daun (Yukamgo dan Nasih, 2007). Silika dapat direduksi menjadi ukuran yang lebih kecil dengan teknologi nano (nanotecnology) menjadikan ukurannya $\left(10^{-9} \mathrm{~m}\right)$. Penggunaan nanosilika agar lebih meningkatkan ketersediaan penyerapan unsur $\mathrm{Si}$ oleh akar dan daun tanaman serta pemerataan dalam penyebaran Si ke dalam tanah lebih terjamin karena ukurannya yang sangat kecil (Amrullah et al., 2014).

Tujuan penelitian ini adalah untuk mengetahui pengaruh pemberian nanosilika terhadap pertumbuhan dan produksi padi varietas Cempo Merah yang mengalami cekaman kekeringan pada fase pertumbuhan vegetatif dan generatif.

\section{MATERI DAN METODE}

Penelitian telah dilaksanakan pada bulan April 2017 - Juli 2017 di Greenhouse serta Laboratorium Fisiologi dan Pemuliaan Tanaman, Fakultas Peternakan dan Pertanian, Universitas Diponegoro, Semarang.

\section{Materi}

Bahan yang digunakan: benih padi varietas Cempo Merah, pupuk anorganik N (Urea), P (SP36), $\mathrm{K}$ (KCL), pupuk nanosilika, tanah, pupuk kandang. Alat yang digunakan : ember plastik (diameter $30 \mathrm{~cm}$, tinggi $20 \mathrm{~cm}$ ), plastik, amplop, label, gunting, kamera, dan alat tulis. 


\section{Metode}

Media tanam berupa tanah sebanyak $7 \mathrm{~kg}$ dimasukkan dalam ember dan disusun sesuai rancangan penelitian. Penjenuhan media tanam dilakukan dengan pemberian air hingga mencapai permukaan ember. Pemupukan dasar menggunakan pupuk bokashi dilakukan sekali pada 7 hari sebelum tanam, yaitu sebanyak $35 \mathrm{~g} /$ pot. Pemupukan kimia dilakukan sesuai dosis rekomendasi yang dilakukan sebanyak tiga kali, yaitu pada umur 15 HST diberikan pupuk urea $0,16 \mathrm{~g} \mathrm{~N} /$ pot, $\mathrm{SP} 360,16 \mathrm{~g} \mathrm{P}_{2} \mathrm{O}_{5} /$ pot, dan $\mathrm{KCl}$ $0,08 \mathrm{~g} \mathrm{~K}_{2} \mathrm{O} /$ pot. Pemupukan kedua Umur $25-30$ HST diberikan urea $0,16 \mathrm{~g} \mathrm{~N} /$ pot. Pemupukan ketiga umur 40 - 45 HST diberikan urea $0,16 \mathrm{~g} \mathrm{~N} /$ pot dan $\mathrm{KCL} 0,08 \mathrm{~K}_{2} \mathrm{O}$ g/ pot.

Perlakuan cekaman kekeringan dilakukan melalui pendekatan pengaturan pemberian air, yaitu penyiraman dengan selang waktu 5 hari sekali untuk perlakuan kontrol (K0) Tidak dilakukan penyiraman pada umur 20 - 35 HST pendekatan perlakuan cekaman kekeringan pada fase pembentukan anakan (K1), umur $40-55$ HST untuk cekaman kekeringan pada fase pembentukan bunga (K2) dan pada umur $55-70$ HST untuk cekaman kekeringan pada fase pengisian biji (K3).

Aplikasi nanosilika dilakukan dengan penyemprotan sebanyak 4 kali melalui daun dengan kadar $30 \mathrm{ppm}$ atau $6 \mathrm{ml} /$ liter air, dilakukan pada umur 7, 20, 45 dan 60 hari setelah tanam (HST). Parameter pengamatan meliputi jumlah anakan total, jumlah anakan produktif, jumlah biji per malai, jumlah biji per rumpun, dan bobot seribu biji.

\section{Rancangan Percobaan dan Analisis Data}

Rancangan dasar yang digunakan adalah Rancangan Acak Lengkap (RAL) pola faktorial $4 \times 2$ dengan 3 ulangan. Faktor pertama stres kekeringan pada fase pertumbuhan berbeda, yaitu (Kontrol (K0), cekaman kekeringan pada fase pembentukan anakan umur 20 - 35 HST (K1), cekaman kekeringan pada fase pembentukan bunga umur 40 - 55 HST (K2), cekaman kekeringan pada fase pengisian biji umur $55-70$ HST (K3)). Faktor kedua pemupukan nanosilika (tanpa nanosilika (S0), dengan nanosilika (S1)). Data hasil pengamatan dianalisis keragamanya dan dilanjutkan dengan uji jarak berganda Duncan pada taraf $5 \%$.

\section{HASIL DAN PEMBAHASAN}

\section{Jumlah Anakan}

Hasil uji jarak berganda Duncan perlakuan cekaman kekeringan pada fase pertumbuhan berbeda dan pemupukan nanosilika pada jumlah anakan total dan anakan produktif disajikan pada Tabel 1 dan keragaan tanaman disajikan pada Ilustrasi 1.

Hasil uji jarak berganda Duncan menunjukkan bahwa, kekeringan selama 15 hari pada fase pembentukan anakan (20-35 HST) berbeda nyata dengan kontrol dan perlakuan lainnya terhadap parameter anakan total. Hal ini menunjukkan bahwa cekaman kekeringan fase pembentukan anakan terbukti menurunkan jumlah anakan total tanaman padi Cempo Merah. Berdasarkan hasil penelitian Tubur et al. (2012) bahwa periode kekeringan menjelang pembentukan anakan dan pembentukan bunga secara nyata menurunkan jumlah anakan total berturut-turut sebesar 22,5\% dan 8,7\% dibanding kontrol. Cekaman kekeringan juga berpengaruh dalam menurunkan jumlah anakan per rumpun pada padi gogo (Supriyanto, 2013).

Pemberian air sangat berpengaruh pada saat fase vegetatif tanaman, terutama untuk pembentukan anakan serta proses pertumbuhan dan perkembangan selanjutnya. Air berperan dalam proses pembentukan, pembelahan, pemanjangan dan perkembangan sel pada jaringan meristematis. Sehingga kekurangan air akan menghambat proses pembentukan jaringan dan organ tanaman, seperti halnya pada organ anakan. Hal ini sesuai dengan pendapat Sujinah dan Ali (2016) bahwa pertumbuhan tanaman padi terjadi karena pembelahan, pembesaran dan diferensiasi sel yang dipengaruhi oleh ketersediaan air, dimana proses fisiologis tersebut sangat sensitif terhadap kekeringan. Diperkuat oleh pendapat Effendi (2008) bahwa cekaman air menyebabkan turgor sel menurun dan selanjutnya menghambat laju pembelahan sel, sehingga laju pertumbuhan organ anakan akan terhambat.

Jumlah anakan total yang terbentuk pada cekaman fase awal pembungaan (30-55 HST) dan pengisian biji (55-70 HST) tidak berbeda nyata 
Tabel 1. Jumlah Anakan Total dan Anakan Produktif Padi Cempo Merah terhadap Cekaman Kekeringan dan Pemberian Nanosilika.

\begin{tabular}{lccc}
\hline \multirow{2}{*}{ Cekaman (K) } & \multicolumn{2}{c}{ Silika (S) } & Rerata \\
\cline { 2 - 4 } & Tanpa Si & Dengan Si \\
\hline Kontrol & ------- jumlah anakan total (anakan)-------- & $17,83^{\mathrm{a}}$ \\
$20-35$ HST & 18,67 & 17,00 & $15,17^{\mathrm{b}}$ \\
$40-55$ HST & 15,00 & 15,33 & $17,67^{\mathrm{a}}$ \\
$55-70$ HST & 17,00 & 20,67 & $18,83^{\mathrm{a}}$ \\
\hline Rerata & 17,00 & 18,33 & \\
\hline & 16,92 & 18,33 & $13,33^{\mathrm{a}}$ \\
Kontrol & 13,00 & $8,00^{\mathrm{b}}$ \\
$20-35$ HST & 7,33 & $15,67^{\mathrm{a}}$ \\
$40-55$ HST & 13,00 & 13,67 & $13,33^{\mathrm{a}}$ \\
$55-70$ HST & 11,33 & 18,33 & \\
\hline Rerata & $11,17^{\mathrm{b}}$ & 15,33 & \\
\hline
\end{tabular}

- Superskrip yang berbeda pada kolom atau baris yang sama menunjukkan perbedaan nyata $(\mathrm{P}<0,05)$

dengan kontrol. Hal ini menunjukkan bahwa perlakuan kekeringan menjelang pembungaan dan pengisian biji tidak berpengaruh pada jumlah anakan total yang terbentuk. Pada kedua perlakuan tersebut, tanaman tidak mengalami cekaman kekeringan pada masa pertumbuhan vegetatif, perlakuan cekaman baru diberikan pada saat tanaman masuk pada tahap pertumbuhan generatif. Hal ini sesuai dengan pendapat Sulistyo et al. (2016) kekeringan pada padi Ciherang ketika fase vegetatif akan menurunkan jumlah anakan, tinggi tanaman serta jumlah daun, sedangkan pada fase generatif akan meningkatkan persen gabah hampa dan penurunan bobot gabah. Diperkuat oleh pendapat Effendi (2008) pada fase generatif, tanaman akan lebih banyak mendistribusikan hasil fotosintat pada organ-organ generatif dibanding untuk pertumbuhan tinggi atau pertumbuhan organ vegetatif lainya.

Hasil uji jarak berganda Duncan menunjukkan bahwa, nanosilika (S1) tidak berbeda nyata dengan tanpa nanosilika (S0). Pemberian nanosilika meningkatkan jumlah anakan total, meskipun belum secara nyata. Pemupukan nanosilika melalui daun menghasilkan jumlah anakan total lebih tinggi dibanding tanpa nanosilika. Hal ini menunjukkan bahwa peran nanosilika dalam mengkonservasi air dalam tanaman belum optimal dalam proses pembentukan anakan total, tetapi peran nanosilika bermakna pada jumlah anakan produktif (Tabel 1). Hal ini sesuai dengan pendapat Ahadiyat dan Harjoso (2010) bahwa pemberian silika belum optimal dalam menurunkan kebutuhan air tanaman, terutama bagi tanaman yang tumbuh pada tanah yang sangat kering.

Hasil uji jarak berganda Duncan menunjukkan bahwa, cekaman kekeringan pada fase pembentukan anakan (20-35 HST) berbeda nyata dengan kontrol dan perlakuan lainnya terhadap parameter anakan produktif. Perlakuan cekaman pada fase pembentukan anakan menunjukkan jumlah anakan produktif paling rendah. Hal ini disebabkan oleh jumlah anakan total yang terbentuk pada perlakuan cekaman kekeringan awal pembentukan anakan sangat rendah, sehingga anakan yang terbentuk menyisakan anakan produtif/ malai yang terbentuk juga sedikit. Hal ini dipengaruhi oleh keadaan anakan yang terbentuk tidak dalam kondisi bugar 


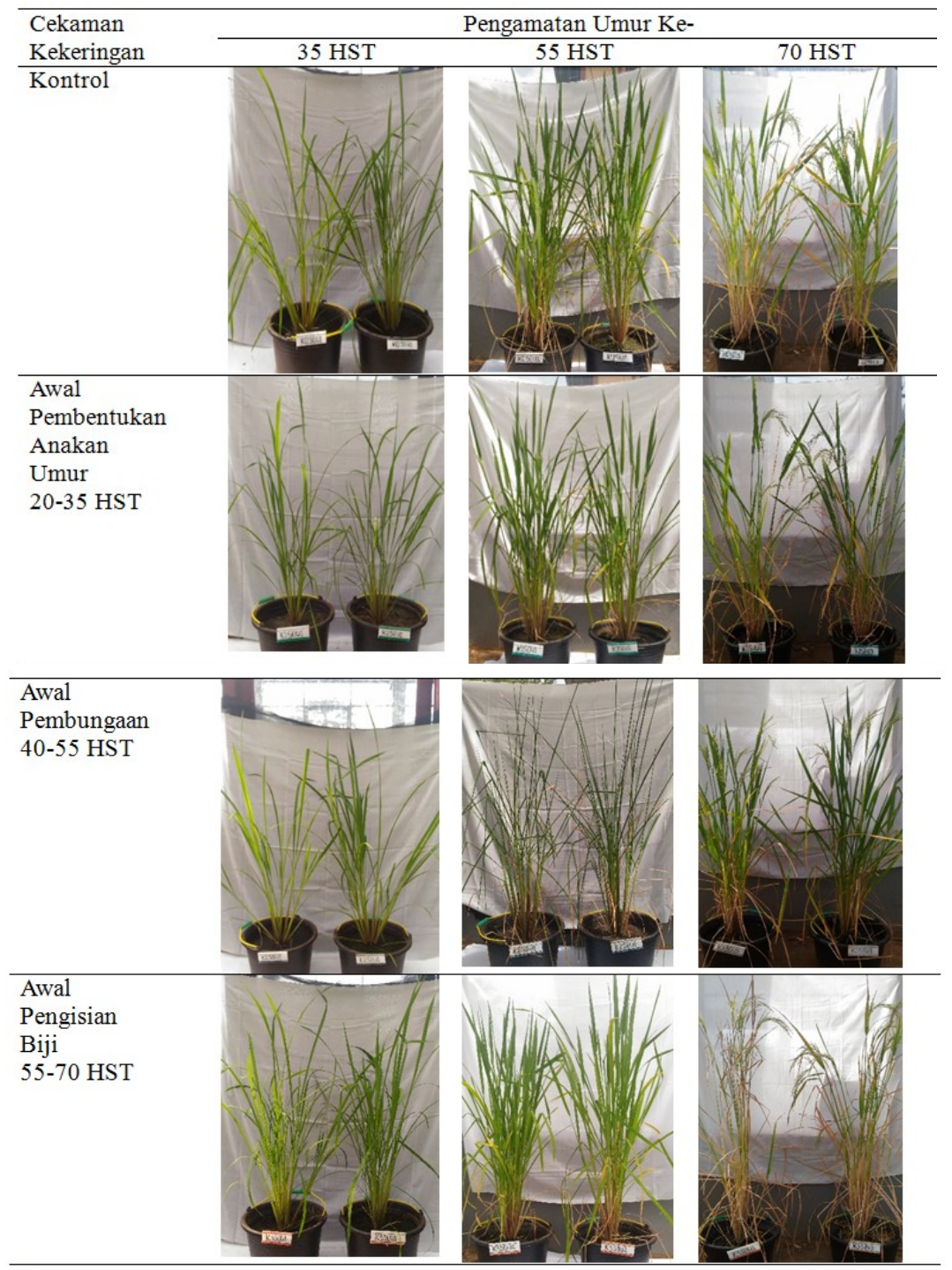

Ilustrasi 1. Keragaan Tanaman Padi Cempo Merah yang Mendapatan Cekaman Kekeringan pada Fase Pertumbuhan Berbeda Umur 35, 55, dan 70 HST.

dan sehat, sehingga sebagian anakan tersebut mengalami hambatan pertumbuhan dan perkembangan, sehingga tidak menghasilkan malai. Cekaman kekeringan pada fase vegetatif berpengaruh sangat nyata dalam mengurangi jumlah anakan produktif (Sulistyono et al., 2012) yang berlanjut pada penurunan jumlah malai yang terbentuk (Edi et al., 2015; Sujinah dan Ali, 2016).

Perlakuan cekaman kekeringan menjelang pembungaan (40-55 HST) menghasilkan jumlah anakan produktif paling tinggi, meskipun tidak berbeda nyata dengan kontrol dan perlakuan cekaman menjelang pengisisan biji (55-70 HST). Hal ini menunjukkan bahwa, cekaman kekeringan menjelang pembungaan tidak berpengaruh dalam menurunkan jumlah anakan produktif. Hal ini dikarenakan tanaman dicekam ketika memasuki fase awal pembungaan, yaitu ketika tanaman dalam masa pertumbuhan generatif, sehingga tidak akan mempengaruhi pembentukan jumlah anakan produktif. Sabetfar et al. (2013) menyatakan bahwa pertumbuhan tanaman padi 
lebih rentan terhadap kekeringan pada fase pembentukan anakan dan inisiasi malai, dibanding pada fase pembungaan. Diperkuat oleh pendapat Ruminta et al. (2016) bahwa jumlah anakan produktif berkorelasi dengan jumlah malai.

Hasil uji jarak berganda Duncan menunjukkan bahwa, nanosilika (S1) menyebabkan perbedaan yang nyata pada jumlah anakan produktif. Pemberian nanosilika belum meningkatkan jumlah anakan total tetapi meningkatkan jumlah anakan produktif. Pemberian nanosilika menghasilkan jumlah anakan produktif lebih banyak dibanding tanpa nanosilika. Hal ini sesuai dengan pendapat Amrullah et al. (2014) tanaman padi yang diberi nanosilika koloid (NSK) 20 ppm mempunyai jumlah anakan total paling banyak dibanding kontrol dan perlakuan lainya. Hal ini menunjukkan bahwa nanosilika berperan aktif dalam meningkatkan jumlah anakan produktif ketika tanaman dalam kondisi kekeringan. Silika mampu menjaga kebugaran tanaman dan meningkatkan ketahanan tanaman terhadap cekaman kekeringan. Beberapa peneliti melaporkan bahwa pemberian silika (Si) meningkatkan ketahanan kekeringan tanaman padi (Makarim et al., 2007), enam belas kultivar sorgum (Kristanto, 2016).

\section{Produksi Padi}

Hasil uji jarak berganda Duncan perlakuan cekaman kekeringan pada fase pertumbuhan berbeda dan pemupukan nanosilika pada jumlah gabah per malai, bobot gabah per rumpun, dan bobot seribu biji disajikan pada Tabel 2 .

Hasil uji jarak berganda

Duncan

Tabel 2. Jumlah Gabah Per Malai, Bobot Gabah Per Rumpun dan Produksi Gabah Tanaman Padi Cempo Merah terhadap Cekaman Kekeringan dan Pemberian Nanosilika.

\begin{tabular}{lccc}
\hline \hline \multirow{2}{*}{ Cekaman (K) } & \multicolumn{2}{c}{ Silika (S) } & Rerata \\
\cline { 2 - 4 } & Tanpa Si & Dengan Si \\
\hline Kontrol & --------- jumlah gabah per malai (biji)---------- & \\
$20-35$ HST & 90,92 & 101,45 & 96,18 \\
$40-55$ HST & 59,69 & 81,75 & 70,72 \\
$55-70$ HST & 93,42 & 99,60 & 96,51 \\
\hline Rerata & 94,24 & 98,31 & 96,27 \\
\hline & 84,57 & 95,28 & \\
Kontrol & 24,20 & $27,24^{\mathrm{a}}$ \\
20-35 HST & 10,30 & $12,56^{\mathrm{b}}$ \\
$40-55$ HST & 19,05 & 30,27 & $25,29^{\mathrm{a}}$ \\
$55-70$ HST & 15,22 & 14,82 & $19,75^{\mathrm{ab}}$ \\
\hline Rerata & $17,19^{\mathrm{b}}$ & 31,54 & \\
\hline & 24,29 & $20,20^{\mathrm{a}}$ \\
Kontrol & 18,85 & $25,23^{\mathrm{a}}$ & $21,95^{\mathrm{a}}$ \\
$20-35$ HST & 23,18 & 21,56 & $16,04^{\mathrm{b}}$ \\
$40-55$ HST & 14,73 & 20,72 & $15,06^{\mathrm{b}}$ \\
55-70 HST & 14,21 & 17,35 & \\
\hline Rerata & 17,74 & 15,91 & \\
\hline
\end{tabular}

- Superskrip yang berbeda pada kolom atau baris yang sama menunjukkan perbedaan nyata $(\mathrm{P}<0,05)$ 
menunjukkan bahwa, tidak ada perbedaan jumlah gabah per malai akibat cekaman kekeringan. Cekaman kekeringan pada saat menjelang pembentukan anakan (20-35 HST) menghasilkan jumlah biji per malai paling rendah terhadap kontrol dan perlakuan lainya. Pada perlakuan tersebut terjadi hambatan pembentukan anakan, sehingga menurunkan jumlah anakan total dan anakan produktif (Tabel 1). Rendahnya jumlah anakan yang membentuk malai akan berdampak pula pada jumlah gabah yang dihasilkan, jika jumlah malai sedikit maka jumlah gabah per malai akan turun. Hal ini sesuai dengan pendapat Tubur et al. (2012) terdapat interaksi antara periode kekeringan dengan varietas terhadap jumlah anakan produktif, presentase pembungaan dan jumlah gabah per malai. Jumlah malai berkolerasi dengan hasil produksi padi, karena semakin sedikit jumlah malai, maka makin sedikit hasil tanaman padi (Edi et al., 2015).

Perlakuan cekaman pada awal pembentukan anakan (20-35 HST) telah mengalami cekaman kekeringan ketika tanaman masih sangat muda, sehingga proses fotosintesis tidak berjalan dengan baik dan menurunkan jumlah padi per malai. Hasil penelitian Nugraheni (2012) bahwa kegiatan fotosintesis mempengaruhi jumlah gabah per malai, dimana jumlah gabah setiap malai tergantung kepada kegiatan tanaman selama fase reproduksi. Zat pati pada butir berasal dari dua sumber yaitu dari hasil asimilasi sebelum pembungaan yang disimpan dalam jaringan batang dan hasil asimilasi selama fase pematangan (Ruminta et al., 2016).

Perlakuan kekeringan menjelang pembungaan (40-55 HST) dan pengisian biji (5570 HST) menghasilkan jumlah biji permalai paling tinggi meskipun belum secara nyata. Hal ini menunjukkan bahwa, ketika tanaman dalam keadaan tercekam kekeringan pada awal masa pembungaan dan pengisian biji masih mampu menghasilkan jumlah gabah permalai lebih tinggi dan tidak berbeda nyata dengan kontrol. Penelitian Tubur et al. (2012) jika kekeringan terjadi sejak masa pembungaan dan pengisian biji relatif tidak memberikan pengaruh terhadap turunya presentase hasil produksi tanaman padi. Semakin kecil nilai persen penurunan produksi artinya tanaman semakin mampu mempertahankan produktivitas pada kondisi cekaman, dengan kata lain tanaman semakin toleran terhadap cekaman kekeringan (Sulistyo et al., 2016).

Pemupukan nanosilika (S1) menghasilkan jumlah biji per malai lebih tinggi dibanding tanpa nanosilika ( $\mathrm{S} 0$ ), meskipun tidak menunjukkan hasil yang berbeda nyata. Hal ini sesuai dengan pendapat Tampoma et al. (2017) bahwa pemberian silika tidak menghasilkan perbedaan yang nyata pada dua kultivar padi lokal poso, namun pemberian silika menghasilkan jumlah gabah per malai lebih tinggi dibanding tanpa silika.

Hasil uji jarak berganda Duncan menunjukkan bahwa, cekaman kekeringan menjelang pembentukan anakan (20-35 HST) berbeda nyata dengan cekaman menjelang pembungaan (40-55 HST) dan kontrol, namun tidak berbeda nyata dengan cekaman menjelang pengisian biji (55-70) terhadap parameter bobot gabah per rumpun. Hal ini menunjukkan bahwa cekaman kekeringan pada masa pembentukan anakan dan pengisian biji mampu menurunkan bobot gabah perumpun. Perlakuan cekaman menjelang pembentukan anakan memiliki bobot gabah per rumpun terendah, karena bobot gabah berkorelasi dengan sedikitnya jumlah anakan produktif yang terbentuk. Hasil penelitian Tubur et al. (2012) periode kekeringan pada fase pembentukan anakan dapat menurunkan produksi gabah hingga $80 \%$ dikarenakan rendahnya jumlah anakan yang terbentuk.

Bobot gabah per rumpun terendah kedua diperoleh pada perlakuan cekaman menjelang pengisian biji (55-70 HST). Pada perlakuan ini tanaman dicekam ketika masuk fase pengisian biji, sehingga penghentian penyiraman menyebabkan banyaknya biji yang kosong, hal inilah yang akan mempengaruhi bobot biji per rumpun. Hasil penelitian Effendi (2008) penurunan berat gabah per rumpun nyata pada semua varietas padi yang diujikan akibat peningkatan intensitas cekaman kekeringan. Diperkuat oleh pendapat Sulistyo et al. (2016) kekeringan pada fase reproduktif dapat meningkatkan persen gabah hampa dan menurunkan bobot gabah.

Hasil uji jarak berganda Duncan menunjukkan bahwa, aplikasi nanosilika (S1) berbeda nyata dengan tanpa nanosilika (S0) terhadap bobot gabah per rumpun. Nanosilika mampu meningkatkan bobot gabah perumpun sebesar 25,23 g dibanding tanpa nanosilika 
sebesar 17,19 g. Hasil penelitian Tampoma et al. (2017) pemberian silika mengasilkan bobot gabah per rumpun lebih besar pada padi kultivar lokal Poso. Silika memberikan pengaruh yang nyata terhadap serapan $\mathrm{Si}$ tanaman, jumlah anakan maksimum dan bobot gabah (Yohana et al., 2013).

Hasil uji jarak berganda Duncan menunjukkan bahwa, cekaman kekeringan pada awal pembungaan dan pengisian biji (40-55 HST) menghasilkan bobot seribu biji nyata lebih rendah dibanding pada perlakuan cekaman awal pembentukan anakan dan kontrol. Bobot seribu biji pada perlakuan cekaman awal berbunga dan pengisian biji menunjukkan nilai terendah yaitu $16,04 \mathrm{~g}$ dan $15,06 \mathrm{~g}$. Rendahnya bobot seribu biji akibat cekaman kekeringan pada fase tersebut sangat berkaitan dengan pembentukan bunga, fertilitas putik dan benang sari, penyerbukan, serta kandungan klorofil daun. Cekaman kekeringan berpengaruh pada sterilisasi bunga, menurunya viabilitas benang sari, dan absorsi bakal biji sehingga menurunkan jumlah butir biji pada tanaman jagung (Lack et al., 2012). Cekaman kekeringan juga akan berdampak pada organ malai dan biji, sehingga menyebabkan penurunan hasil biji dan bobot seribu biji pada tanaman shorgum manis (Kristanto et al., 2016)

Bobot seribu biji tertinggi diperoleh pada perlakuan cekaman kekeringan awal pembentukan anakan, meskipun tidak berbeda dengan perlakuan kotrol. Hasil penelitian Ruminta et al. (2016) teknik pemberian air secara berselang pada tanaman padi menghasilkan bobot seribu biji lebih berat dibanding pengairan secara macakmacak, karena pertumbuhan jaringan akar lebih sempurna sehingga pengangkutan unsur hara lebih lancar. Salah satu faktor yang juga mempengaruhi persamaan bobot seribu biji antar perlakuan cekaman umur 20-35 HST dengan kontrol adalah keseragaman biji. Berdasarkan hasil penelitian Nirmala et al. (2016) bobot 100 biji tanaman hanjeli tidak berbeda nyata dengan kontrol diduga karena hasil biji mempunyai ukuran yang hampir seragam pada setiap perlakuan.

Tanaman yang mendapatkan cekaman kekeringan ketika masa awal pembentukan anakan (20-35 HST) selama 15 hari, kemudian disiram hingga panen, sehingga tanaman mengalami pemulihan kembali (recovery). Pemulihan terus berlangsung dan berpengaruh pada peningkatan bukaan stomata (Flexas et al., 2009) dan fotosintesis sehingga tanaman melanjutkan pertumbuhan (Xu et al., 2010). Beberapa peneliti melaporkan, bahwa pemulihan akibat penyiraman meningkatkan fotosintesis (Miyashita et al., 2005; Bogeat - Triboulot et al., 2007; Galle et al., 2007), yang berlanjut pada peningkatan hasil biji dan bobot seribu biji (Sabiel et al., 2014; Kristanto, 2016).

Pemberian nanosilika (S1) mengasilkan bobot seribu biji lebih tinggi dibanding tanpa nanosilika meskipun belum secara nyata. Hasil penelitian Tampoman et al. (2017) bahwa dosis silika $1 \mathrm{~L} /$ ha menghasilkan bobot seribu biji lebih tinggi namun tidak berdeda nyata dengan dosis silika 1,5 L/ha. Hal tersebut juga diduga karena pemupukan nanosilika yang disemprotkan langsung pada daun tanaman, akan lebih efektif jika dilakukan pemupukan melalui tanah. Hasil penelitian Yukamgo dan Nasih (2007) Si dalam tanah akan meningkatkan konsentrasi asam monosilikat yang akan mengubah $\mathrm{P}$ tidak larut menjadi $\mathrm{P}$ tersedia bagi tanaman. Sejalan dengan penelitian Zulputra et al. (2014) adanya penambahan silika akan meningkatkan ketersediaan Si di dalam tanah, sehingga serapan unsur tersebut dan kadarnya di dalam jaringan tanaman meningkat. Syahri et al. (2016) karena unsur $\mathrm{Si}$ yang diberikan melalui tanah dapat mempengaruhi ketersediaan unsur fosfor dalam tanah sehingga rendemen tebu akan lebih tinggi daripada Si yang diberikan melalui daun.

\section{KESIMPULAN}

Berdasarkan hasil penelitian dapat disimpulkan bahwa cekaman kekeringan pada fase pembentukan anakan menurunkan jumlah anakan total, anakan produktif dan bobot gabah per rumpun, tetapi tidak berpengaruh pada bobot seribu biji. Cekaman kekeringan pada fase pembentukan bunga dan pengisian biji tidak menurunkan jumlah anakan total, anakan produktif, jumlah gabah per malai dan bobot gabah per rumpun, tetapi menurunkan bobot seribu biji. Pemberian nanosilika meningkatkan jumlah anakan produktif dan bobot gabah per rumpun. Tidak ada Interaksi antara perlakuan cekaman kekeringan dan pemupukan nanosilika pada semua parameter yang diujikan. 


\section{DAFTAR PUSTAKA}

Ahadiyat, Y.R. dan T. Harjoso. 2010. Karakter Agronomis dan Fisiologis Padi Gogo Yang Ditanam Pada Media Tanah Bersekam Pada Kondisi Air Dibawah Kapasitas Lapang. Akta Agrosia. In press.

Amrullah, D. Soepandie, Sugianta, dan A. Junaedi. 2014. Peningkatan produktivitas tanaman padi (Oryza sativa L.) melalui pemberian nano silika. PANGAN. 23 (1): 17-32.

Balai Penelitian Tanah. 2011. Sumber hara silika untuk pertanian. Warta Penelitian dan Pengembangan Pertanian. 33 (3): 12-13.

Bogeat - Triboulot, M-B., M. Teichmann, A. Altman, J. F. Hausman, A. Polle, J. Kangasjarvi and E. Dreyer. 2007. Gradual soil water depletion results in reversible changes of gene expression, protein profiles, ecophysiology, and growth performance in Populus euphratica, a poplar growing in arid regions. Plant Physiol. 143: 876-892.

Effendi, Y. 2008. Kajian Resistensi Beberapa Varietas Padi Gogo (Oryza sativa L.) terhadap Cekaman Kekeringan. Program Pascasarjana Universitas Sebelas Maret, Surakarta. (Tesis Magister Pertanian).

Flexas, J., M. Baron, J. Bota, J. M. Ducruet, A. Galle, J. Galmés , M. Jimenez, A. Pou, H M. Ribas-Carbo, C. Sajnani, M. Tomas and H. Medrano. 2009. Photosynthesis limitations during water stress acclimation and recovery in the drought-adapted Vitis hybrid Richter-110 ( $V$. berlandieri $\mathrm{x}$ V. rupestris). J. Exp Bot 60: 2361-2377.

Galle, A., P. Haldimann and U. Feller. 2007. Photosynthetic performance and water relations in young pubescent oak (Quercus pubescens) trees during drought stress and recovery. New Phytol 174: 799-810

Indriyani, F., Nurhidajah., dan A. Suyanto. 2013.
Karakteristik fisik, kimia dan sifat organolepik tepung beras merah berdasarkan variasi lama pengeringan. J. Pangan dan Gizi. 4 (8): 27-34.

Kristanto, B. A. 2016. Tanggapan Sorgum Manis (Sorghum bicolor (L.) Moench) terhadap Cekaman Kekeringan dan Pemupukan Silika. Program Pascasarjana Universitas Gadjah Mada, Yogyakarta. (Disertasi Doktor Pertanian).

Kristanto, B. A., D. Indradewa, A. Ma'as, dan R. D. Sutrisno. 2016. Pengaruh perbedaan sumber silika dalam menginduksi ketahanan kekeringan dan produksi biji sorgum manis (Sorghum bicolour (L.) Moerch dalam kondisi stres kekeringan. Prosiding Seminar Nasional Fakultas Pertanian. Surakarta, 5 Desember 2016. Universitas Slamet Riyadi Surakarta. Hal. 31-39

Lack, S., H. Dashti, G. Abadooz, and A. Modhej. 2012. Effect of different levels of irrigation and planting pattern on grain yield, yield components and water use efficiency of corn grain (Zea mays L.) hybrid SC. 704. Afric J Agric Res 7: 2873-2878.

Makarim, A. K., dan E. Suhartatik. 2009. Morfologi dan Fisiologi Tanaman Padi. Balai Besar Penelitian Tanaman Padi.

Makarim, A. K., E. Suhartatik., dan A. Kartohardjono. 2007. Silikon: hara penting pada sistem produksi padi. Iptek Tanaman Pangan 2 (2): 195-210.

Miyashita, K., S. Tanakamaru, T. Maitani and K. Kimura . 2005. Recovery responses of photosynthesis, transpiration, and stomatal conductance in kidney bean following drought stress. Environ. and Exp. Botany. 53: 205-214.

Nirmala, T., A. Yuniarti, dan N. Syahfitri. 2016. Pengaruh berbagai dosis pupuk silika organik dan tingkat kekerasan biji terhadap pertumbuhan dan hasil tanaman hanjeli pulut (Coix lacryma jobi L) genotip 37. J. 
Kultivasi. 15 (2): 133-142.

Nugraheni, L. 2012. Pertumbuhan, Hasil dan Kualitas Hasil Dua Varietas Padi Hitam dengan Pemupukan Organik dan Anorganik. Program Pasca Sarjana Universitas Sebelas Maret, Surakarta. (Tesis Magister Pertanian).

Pikukuh, P., Djajadi, S. Y. Tyasmoro, dam N. Aini. 2015. Pengruh frekuensi dan konsentrasi penyemperotan pupuk nano silika (Si) terhadap pertumbuhan tanaman tebu (Saccharum officinarum L.) J. Produksi Tanaman. 3 (3): 249-258.

Kementerian Pertanian. Pusat Data dan Sistem Informasi Pertanian Kementerian Pertanian. 2015. Outlook Komoditas Pertanian Subsektor Tanaman Pangan (Padi).

Putri, F. M., S. W. A. Suedy, dan S. Darmanti. 2017. Pengaruh pupuk nanosilika terhadap jumlah stomata, kandungan klorofil, dan pertumbuhan padi hitam (Oryza sativa L. Cv. Japonica). Buletin Anatomi dan Fisiologi. 2 (1): 72-79.

Ruminta, S. Rosniawaty, dan A. Wahyudin. 2016. Pengujian sensitivitas kekeringan dan daya adaptasi tujuh varietas padi di wilayah dataran medium Jatinagor. J. Kultivasi. 15 (2): $114-120$.

Sabetfar, S., M. Ashouri, E. Amiri, and S. Babazadeh. 2013. Effect of drought stress at different growth stages on yield and yield component of rice plant. Persian Gulf Crop Protection. 2 (2): 14-18.

Sabiel, S..A..I., A. A. Abdelmula, E. M. A. Bashir, S. U. Baloch, S. K. Baloch and W. Bashir. 2014. Genetic variation of flowering trait in maize (Zea mays L.) under drought stress at vegetative and reproductive stages. J Biol Agric Healthcare. 4 (20): 108-113.

Sujinah dan A. Jamil. 2016. Mekanisme respon tanaman padi terhadap cekaman kekeringan dan varietas toleran. Iptek Tanaman Pangan.
$11(1): 1-8$

Sulistyo, R., A. Yunus, dan Nandariyah. 2016. Keragaman padi Ciherang M2 hasil radiasi Gamma pada stres kekeringan. Agrotech Res J. 5 (1): 19-23.

Sulistyono, E., Suwarno, dan I. Lubis. 2012. Karakterisasi morfologi dan sisiologi untuk mendapatkan marka morfologi dan fisiologi padi sawah tanah kekeringan $(-30 \mathrm{kPa})$ dan produktivitas tinggi $(>8 \mathrm{t} / \mathrm{ha})$. Jurnal Ilmu Pertanian Indonesia (JIPI). 17 (2): 96-102.

Supriyanto, B.. 2013. Pengauh cekaman kekeringan terhadap pertumbuhan dan hasil padi gogo lokal kultivar jambu. J. AGRIFOR. 12 (1): 77-82.

Syahri, R., Djajadi, T. Sumarni, dan A. Nugroho. 2016. Pengaruh pupuk hijau (Crotalaria juncea L.) dan konsentrasi pupuk nano silika pada pertumbuhan dan hasil tebu setelah umur 9 bulan. J. Produksi Tanaman. 4 (1): 73-81.

Tampoma, W. P., T. Nurmala, dan M. Rachmadi. 2017. Pengaruh dosis silika terhadap karakter fisiologi dan hasil tanaman padi (Oryza sativa L.) kultivar lokal poso (kultivar 36-Super dan Tagolu). J. Kultivasi. 16 (2): 320-325.

Tubur, H. W., M. A. Chozin., E. Santosa, dan A. Junaedi. 2012. Respon agronomi varietas padi terhadap periode kekeringan pada sistem sawah. J. Agron. Indonesia. 40 (3): 167-173.

Xu, Z., G. Zhou and H. Shimizu. 2010. Plant responses to drought and rewatering. Plant Signal Behav. 5: 649-654.

Yukamgo, Edo dan N. W. Yuwono. 2007. Peran silikon sebagai unsur bermanfaat pada tanaman tebu. Jurnal Ilmu Tanah dan Lingkungan. 7 (2): 102-116.

Yohana, O., H. Hanum, dan Supriadi. 2013. Pemberian bahan silika pada tanah sawah 
berkadar $\mathrm{P}$ total tinggi untuk memperbaiki ketersediaan $\mathrm{P}$ dan Si tanah, pertumbuhan dan produksi padi (Oryza sativa L.). J. Online Agroekoteknologi. 4 (1): 1444-1452.
Zulputra, Wawan dan Nelva. 2014. Respon padi gogo (Oryza sativa L.) terhadap pemberian silikat dan pupuk fosfat pada tanah ultisol. J. Agroteknologi. 4 (2): 1-10. 